\title{
Analisis Perencanaan Peningkatan Infrastruktur Tik Di Politeknik Negeri Balikpapan
}

\author{
Armin $^{1)}$, Erick Sorongan ${ }^{2)}$ \\ ${ }^{1), 2)}$ Program Studi Teknik Elektronika \\ Politeknik Negeri Balikpapan \\ Jl. Soekarno Hatta Km. 8 Balikpapan 76129, Telp./Fax. 0542 860895/861107 \\ Email : armin@ poltekba.ac.id ${ }^{1)}$, erick.sorongan@ poltekba.ac.id ${ }^{2}$
}

\begin{abstract}
The need for support of IT (Information Technology) is now considered increasingly important in achieving competitive advantage for a company or organization. Exploiting the advantages of IT needs the ability to manage IT resources into an effective IT governance so as to create efficient business processes and excel in achieving the vision of an organization. Organizations should have full awareness in seeing any benefits to be achieved through IT, therefore it takes the role of management in making IT investments that are right for their organization's needs. A good IT project should follow four basic stages include (1) planning, (2) procurement, (3) implementation, and (4) surveillance. If the organization can manage all four stages well, it can certainly benefit from IT investments more dominant intangible can be perceived by all IT human resources. This study aimed to analyze the planning of infrastructure improvement of Information and Communication Technology at the State Polytechnic of Balikpapan. Methods of research conducted through several phases ranging from the needs analysis, to determine the exact needs of the ICT infrastructure for the current business model and future with reference to a best practice recommendation. From the analysis showed Poltekba need support technology infrastructure (hardware) that can increase network capacity, data, and IT security in the campus environment.
\end{abstract}

Keywords : Infrastructure TIK, Improving TIK, TIK

\begin{abstract}
Abstrak
Kebutuhan akan dukungan keunggulan TI (Teknologi Informasi) saat ini dirasakan semakin penting dalam mencapai keunggulan kompetitif bagi sebuah perusahaan atau organisasi. Pemanfaatan keunggulan TI membutuhkan kemampuan dalam mengelola sumber daya TI kedalam sebuah tata kelola TI yang efektif sehingga dapat menciptakan proses bisnis yang efisien dan unggul dalam mencapai visi sebuah organisasi. Organisasi harus memiliki kesadaran penuh dalam melihat setiap manfaat yang bisa diraih melalui TI, oleh karena itu dibutuhkan peran serta manajemen dalam melakukan investasi TI yang tepat bagi kebutuhan organisasi mereka. Sebuah proyek TI yang baik harus mengikuti empat tahap dasar diantaranya (1) perencanaan, (2) pengadaan, (3) pengimplementasian dan (4) pengawasan. Apabila organisasi dapat mengelola keempat tahapan tersebut dengan baik dapat dipastikan keuntungan dari investasi TI yang lebih dominan bersifat intangible dapat dirasakan oleh seluruh SDM TI. Penelitian ini bertujuan untuk menganalisis perencanaan peningkatan infrastruktur Teknologi Informasi dan Komunikasi di Politeknik Negeri Balikpapan. Metode penelitian yang dilakukan melalui beberapa tahapan mulai dari analisis kebutuhan, sampai dengan penentuan kebutuhan infrastruktur TIK yang tepat untuk model bisnis saat ini dan masa depan dengan mengacu rekomendasi sebuah best practice. Dari hasil analisa menunjukkan Poltekba membutuhkan dukungan infrastruktur teknologi (hardware) yang dapat meningkatakan kemampuan jaringan, data dan kemanan TI di lingkungan kampus.
\end{abstract}

Kata Kunci : Infrastruktur TIK, Peningkatan TIK, TIK 


\section{Pendahuluan}

Bagi kebanyakan organisasi TI menjadi sesuatu yang krusial dalam proses dukungan, keberlanjutan dan pertumbuhan bisnis. Oleh karena itu keberhasilan dalam pencapaian tujuan bisnis bergantung langsung pada tingkat dan kemampuan pemberdayaan teknologi [1]. Peran TI bagi organisasi saat ini tidak hanya sebatas pendukung bagi kelancaran dan kemudahan proses bisnis akan tetapi sudah menjadi driver bagi keberlanjutan layanan yang dihasilkan organisasi. Khusus untuk organisasi pendidikan tinggi TI diposisikan sebagai sarana peningkatan ilmu pengetahuan teknologi dan juga sekaligus untuk memberikan layanan yang maksimal bagi seluruh stakeholder di organisasi tersebut. Hasil survey menunjukkan $67 \%$ perusahaan mengalami mengalami pelanggaran keamanan dan hampir $60 \%$ melaporkan kerugian keuangan akibat pelanggaran keamanan TI, termasuk pada saat kejadian aksi pemboman World Trade Centre di New York City dengan estimasi kerugian ekonomi tahunan akibat kesalahan software sama dengan 60 miliar dolar. Steinbart menyebutkan bahwa setidaknya organisasi menghadapi 4 tantangan terhadap sistem : (1) bencana alam dan politik, (2) software errors dan equipment malfunction, (3) tindakan yang tidak disengaja dan (4) tindakan disengaja [2]. Ini menunjukkan bahwa peran TI sangat berpengaruh bagi keberlanjutan sebuah organisasi, ketika organisasi merencanakan perangkat TI yang tepat untuk mencapai keunggulan kompetitifnya maka sudah selayaknya memperhitungkan mengenai sistem kemanan TI supaya teknologi yang pada awalnya ditujukan untuk menjaga keberlanjutan proses layanan bisnis tidak malah menjadi bencana bagi organisasi tersebut.

Kegiatan peningkatan infrastruktur teknologi informasi dan komunikasi di Politeknik Negeri Balikpapan adalah merupakan langkah strategis yang diambil manajemen TI dalam mendukung organisasi mencapai visi dan keberlanjutan pertumbuhan organisasi. Hal tersebut dapat dilihat dari keselarasan antara renstra TIK dan renstra Poltekba yang memiliki tujuan utama yaitu mendukung Poltekba menjadi institusi unggul dibidang teknologi terapan dengan menerapkan standar internasional. Untuk menghindari dari kesalahan dalam menerapkan TIK yang tepat bagi organisasi, maka dibutuhkan sebuah kegiatan perencanaan yang didahului dengan proses analisis kebutuhannya terlebih dahulu. Salah satu penyebab yang membuat implementasi TI bisa gagal adalah (i) tidak lengkapnya pernyataan kebutuhan dan spesifikasi dan pernyataan kebutuhan, (ii) kurangnya input dari pengguna dan (iii) spesifikasi dan pernyataan kebutuhan yang senantiasa berubah - ubah. Faktor yang dapat mendukung kesuksesan penerapan TI diantaranya adalah : (i) dukungan manajemen eksekutif, (ii) kejelasan pernyataan kebutuhan dan (iv) perencanaan yang tepat [3].

\section{Tinjauan Pustaka}

Organisasi pendidikan pada umumnya telah memanfaatkan TIK untuk mendukung kegiatan bisnis mereka, bahkan tidak jarang sebuah institusi pendidikan tinggi menginvestasikan biaya yang cukup tinggi untuk mengadakan dan mengimplementasikan keunggulan teknologi dengan tujuan meningkatkan kegiatan pembelajaran bagi mahasiswa di kampus. Dari hasil penelitian yang telah dilakukan menunjukkan bahwa penerimaan teknologi sistem ujian online dapat meningkatkan kualitas layanan teknologi, faktor yang berpengaruh adalah perilaku dari pengguna terhadap penerimaan sistem ujian online yang dapat meningkatkan pembelajaran dan suasana yang tertib dan nyaman ketika pelaksanaan ujian[4].

Untuk menjamin layanan bisnis sebuah organisasi tetap terjaga dengan baik maka diperlukan pengelolaan yang efektif guna 
menyebarluaskan dampak TI keseluruh stakeholder yang ada di organisasi. Gomes dan Rebeiro [5] dalam papernya yang berjudul The Main Benefits Of CobIT In A High Public Educational Institution- A Case Study, menggambarkan implementasi ITIL dan CobIT di sebuah Perguruan Tinggi di Portugal utara yang memiliki beberapa sistem informasi yang tersebar dan mendukung aktifitas Perguruan Tinggi tersebut. Oleh karena itu diperlukan suatu mekanisme yang menjamin manajemen dan pengendalian dari sistem informasi khususunya untuk tata kelola TI. Sebagai bagian dari penerapan Sistem Manajemen Mutu IPVC dalam pelaksanaan sertifikasi standar ISO 9001, mengimplementasikan mekanisme untuk membangun tata kelola TI terutama dalam mengelola dan mengendalikan TI dan sistem informasi.

Dapat ditarik kesimpulan bahwa TIK saat ini bisa menjadi tulang punggung bagi kehidupan organisasi oleh karena itu organisasi perlu melakukan peningkatan TIK dengan melihat kebutuhan organisasi saat ini dan kebutuhan dimasa depan. Organisasi tidak dapat mengandalkan infrastruktur TIK yang ada saat ini ketika masalah terkait layanan TI terus meningkat setiap harinya. Hal utama yang penting dilakukan oleh organisasi ketika akan melakukan peningkatan TIK mereka harus melakukan pengelolaan yang baik disisi perencanaan.

\section{Metode Penelitian}

Metodologi dalam penelitian ini meliputi empat tahapan, yaitu :

1. Studi kelayakan penerapan TIK saat ini

2. Analisis kebutuhan TIK yang diharapkan

3. Rekomendasi peningkatan TIK

perencanaan

4. Strategi untuk mencegah kegagalan

\section{Pembahasan}

1. Studi kelayakan penerapan TIK saat ini

Kondisi arsitektur jaringan yang ada saat ini di Poltekba dianggap sudah tidak memadai untuk menjalankan berbagai aktivitas yang semakin meningkat setiap saat. Hal ini disebabkan karena banyaknya pengguna yang mengakses jaringan secara bersamaan sehingga mengakibatkan kapasitas host id tidak mencukupi untuk menampung pengakses jaringan baru. Berikut ini akan digambarkan arsitektur yang berjalan saat ini dan beberapa masalah yang sering muncul, untuk selanjutnya dilakukan tindakan perbaikan ataupun peningkatan dari sisi infrastruktur TIK. Studi kelayakan dilakukan melalui analisis kesenjangan dan pelaksanaan tata kelola TI saat ini.

Tabel 1. 1 Kondisi Akses dan Konektivitas Saat Ini

\begin{tabular}{|c|c|}
\hline Aspek & Analisis Kesenjangan \\
\hline $\begin{array}{l}\text { Akses dan } \\
\text { Konektivitas }\end{array}$ & $\begin{array}{l}\text { 1. Akses Internet } r \text { kampus } \\
\text { menggunakan FO dan ditunjang } \\
\text { dengan layanan Wifi yang telah } \\
\text { mencakup } 80 \% \text { area } \\
\text { POLTEKBA sudah memadai } \\
\text { dengan kebutuhan. Masalah } \\
\text { yang dijumpai saat ini } \\
\text { merupakan masalah minor } \\
\text { terkait dengan reliabilitas } \\
\text { perangkat jaringan. } \\
\text { 2. Perhitungan rasio } \\
\text { bandwidth/mahasiswa di depan } \\
\text { adalah 1,67 kbps/mahasiswa, } \\
\text { dengan asumsi maksimal 30\% } \\
\text { dari total mahasiswa } \\
\text { menggunakan bersama-sama. } \\
\text { Dengan mempertimbangkan } \\
\text { penawaran akses internet yang } \\
\text { ada di lingkungan sekitar } \\
\text { POLTEKBA } \\
\text { Broadband atau Warnet), link } \\
\text { internet sebesar ini sudah sangat } \\
\text { terbatas. POLTEKBA Perlu } \\
\text { untuk mempertimbangkan } \\
\text { memperbesar koneksi internet, } \\
\text { khususnya yang diarahkan } \\
\text { untuk mengakses referensi- } \\
\text { referensi ilmiah internasional } \\
\text { Untuk pola-pola pengaksesan } \\
\text { konten yang lebih cenderung } \\
\text { dalam negeri, dapat } \\
\text { dipertimbangkan untuk lebih }\end{array}$ \\
\hline
\end{tabular}




\begin{tabular}{|l|l|}
\hline & memperbesar koneksi ke IIX \\
\hline
\end{tabular}

Tabel 1. 2 Kondisi Pengelolaan Keamanan TI Saat Ini

\begin{tabular}{|l|l|}
\hline Aspek & Analisis Kesenjangan \\
\hline Pengelolaan & 1. Pengelolaan keamanan TI di \\
TI & level jaringan sudah cukup \\
& memadai, dengan keberadaan \\
& staff yang dedicated. Kekurangan \\
& yang masih ditemui saat ini \\
& adalah peralatan teknologi \\
& keamanan TI yang standar. \\
& 2. Pengelolaan keamanan aplikasi \\
& sepenuhnya bergantung pada \\
& $\begin{array}{l}\text { keamanan jaringan, belum ada } \\
\text { mekanisme standar yang } \\
\text { digunakan seperti pada } \\
\text { penanganan keamanan jaringan }\end{array}$ \\
&
\end{tabular}

Tabel 1. 3 Kondisi Pengelolaan Data Centre Saat Ini

\begin{tabular}{|c|c|}
\hline Aspek & Analisis Kesenjangan \\
\hline \multirow{18}{*}{$\begin{array}{l}\text { DC \& } \\
\text { DRC } \\
\text { (Data } \\
\text { Center \& } \\
\text { Disaster } \\
\text { Recovery } \\
\text { Center) }\end{array}$} & 1. Dari seluruh fasilitas fisik Data \\
\hline & Center yang ada di UPTSI, sistem \\
\hline & HVAC sudah tidak memadai lagi. \\
\hline & Jika terus dipaksa digunakan \\
\hline & berpotensi \\
\hline & mengganggu availabilitas sistem \\
\hline & secara keseluruhan. \\
\hline & 2. Pola manajemen backup yang ada \\
\hline & $\begin{array}{l}\text { saat ini masih memiliki risiko, jika } \\
\text { sesuatu terjadi pada gedung }\end{array}$ \\
\hline & dimana UPTSI berada. Sebagai \\
\hline & $\begin{array}{l}\text { baseline diperlukan DC Backup } \\
\text { yang berada di gedung berbeda } \\
\text { dengan UPTSI. }\end{array}$ \\
\hline & 3. Untuk tahap minimal DC Backup \\
\hline & di gedung \\
\hline & digunakan, walaupun tidak \\
\hline & sepenuhnya bisa menutup risiko \\
\hline & jika terjadi bencana yang \\
\hline & $\begin{array}{l}\text { mengenai seluruh kompleks } \\
\text { POLTEKBA. }\end{array}$ \\
\hline & \\
\hline
\end{tabular}

Berdasarkan hasil penelitian yang dilakukan dengan menggunakan metode Cobit 4.1 [6] di Poltekba juga menemukan beberapa masalah umum yang sering terjadi terkait dengan infrastruktur TIK saat ini, diantaranya adalah :
Tabel 1. 4 Analisis Tata Kelola TI

Menggunakan Cobit 4.1

\begin{tabular}{|c|c|c|}
\hline $\begin{array}{l}\text { No } \\
\text { Proses } \\
\end{array}$ & $\begin{array}{l}\text { Nama } \\
\text { Proses }\end{array}$ & Analisis Kesenjangan \\
\hline PO.04 & $\begin{array}{l}\text { Define the IT } \\
\text { Processes, } \\
\text { Organisation } \\
\text { and } \\
\text { Relationship }\end{array}$ & $\begin{array}{l}\text { Pihak terkait yang ada di } \\
\text { organisasi belum merasa } \\
\text { puas dengan dukungan TI } \\
\text { yang ada selama ini, } \\
\text { penyebab yang banyak } \\
\text { dilaporkan kepada pihak } \\
\text { UPT SI adalah lambatnya } \\
\text { jaringan internet kampus } \\
\text { yang ada. Selain itu juga } \\
\text { adalah kurangnya pasokan } \\
\text { listrik yang sering kali } \\
\text { padam sehingga } \\
\text { menyebabkan beban kerja } \\
\text { server bertambah } 2 \text { kali } \\
\text { lipat karena harus } \\
\text { melakukan proses restart } \\
\text { ulang. }\end{array}$ \\
\hline AI.04 & $\begin{array}{l}\text { Enable } \\
\text { Operation } \\
\text { and Use }\end{array}$ & $\begin{array}{l}\text { Banyak proses bisnis kritis } \\
\text { di Poltekba yang tidak } \\
\text { didukung } \\
\text { infrastruktur } \text { dengan } \\
\text { memadai. } \\
\text { utamanya adalah beberapa } \\
\text { infrastruktur TI yang } \\
\text { dimiliki oleh UPT SI sudah } \\
\text { usang dan harus dilakukan } \\
\text { pembaharuan senyebab } \\
\text { dengan perkembangan } \\
\text { teknologi yang ada saat ini. }\end{array}$ \\
\hline DS.08 & $\begin{array}{l}\text { Manage } \\
\text { Service desk } \\
\text { and Incident }\end{array}$ & $\begin{array}{l}\text { Sering terjadi down time } \\
\text { pada server atau data yang } \\
\text { disebabkan } \\
\text { pasokan listrik dasalah } \\
\text { kelebihan beban. }\end{array}$ \\
\hline DS.08 & $\begin{array}{l}\text { Manage } \\
\text { Service desk } \\
\text { and Incident }\end{array}$ & $\begin{array}{lr}\text { Hal teknis } & \text { yang } \\
\text { mempengaruhi } & \text { bisnis } \\
\text { organisasi diantaranya } \\
\text { internet macet } \\
\text { berhubungan yang } \\
\text { jaringan, kurangnya tenaga } \\
\text { sehingga lambat dalam } \\
\text { melayani dan ada pihak } \\
\text { ketiga dalam melakukan } \\
\text { perbaikan terhadap } \\
\text { perlengkapan TIK yang } \\
\text { mengalami masalah atau } \\
\text { kerusakan. }\end{array}$ \\
\hline
\end{tabular}

Masalah juga sering muncul pada saat mengelola jaringan internet dan komunikasi di kampus Poltekta dan hal tersebut langsung dialami oleh UPTSI sebagai penanggungjawab pengelolaan SI di 
Poltekba. Berikut ini adalah permasalahan yang sering dihadapi UPTSI :

1. Keterbatasan jumlah IP kelas C, jika ada lebih dari 250 user jaringan wireless / kabel yang terkoneksi di 1 (satu) Net ID diwaktu bersamaan dalam jaringan maka user selanjutnya tidak bisa terkoneksi ke jaringan.

2. Tidak adanya teknisi yang standby di gedung elektronika / TMAB sehingga mengharuskan petugas UPTSI ke gedung elektronika / Workshop TMAB ketika terjadi gangguan secara fisik / software.

3. Tidak bisa memonitor / me-remote perangkat yang ada di gedung TMAB dari ruang server UPTSI.

4. Banyaknya komputer dan monitor di Lab komputer yang sudah usang sehingga menyebabkan beberapa komputer tidak berfungsi.

5. Kekurangan SDM untuk mengelola perangkat TIK.

\section{Analisis kebutuhan TIK yang diharapkan}

Untuk mengatasi masalah - masalah terkait dengan infrastruktur TIK yang terjadi saat sekarang di Poltekba, maka akan diambil langkah - langkah perbaikan dan peningkatan. Langkah - langkah tersebut juga akan mempertimbangkan beberapa aspek diantaranya (a) hasil rekomendasi analisis yang sudah dilakukan, (b) kebutuhan infrastruktur dan informasi dan (c) tren TIK saat sekarang dan dimasa depan. Harapan pencapaian dari peningkatan infrastruktur TIK di Poltekba adalah untuk memberikan pelayanan yang memuaskan kepada seluruh pengguna di lingkungan kampus serta bisa mendukung kegiatan perkuliahan bagi seluruh mahasiswa Poltekba yang memanfaatkan TIK. Dari hasil kesepakatan yang telah dilakukan manajemen TI makan Poltekba membutuhkan sebuah data centre yang mampu mengintegrasikan seluruh data kepegawaian dan kemahasiswaan serta pembelajaran kedalam sebuah server yang terintegrasi. Kebutuhan ini dirumuskan setelah melakukan analisis kebutuhan pengguna disetiap program studi yang tersebar di Poltekba.

Tabel 1. 5 Rekomendasi Peningkatan Akses \& Konektifitas

\begin{tabular}{|c|c|c|c|}
\hline Area & $\begin{array}{l}\text { Rekomend } \\
\text { asi }\end{array}$ & Obyektif & $\begin{array}{l}\text { Deskripti } \\
\text { f }\end{array}$ \\
\hline $\begin{array}{l}\text { Aristektur } \\
\text { Infrastruk } \\
\text { tur }\end{array}$ & $\begin{array}{l}\text { Peningkata } \\
\mathrm{n} \text { Akses \& } \\
\text { Konektifita } \\
\mathrm{s}\end{array}$ & $\begin{array}{l}\text { Meningkat } \\
\text { kan } \\
\text { kapasitas } \\
\text { bandwith } \\
\text { internet } \\
\text { atau local } \\
\text { access } \\
\text { dalam } \\
\text { rangka } \\
\text { meningkat } \\
\text { kan } \\
\text { intensitas } \\
\text { akses } \\
\text { referensi } \\
\text { ilmiah dan } \\
\text { kolaborasi } \\
\text { ilmiah }\end{array}$ & $\begin{array}{l}\text { Rekomend } \\
\text { asi ini } \\
\text { mencakup } \\
\text { penambah } \\
\text { an } \\
\text { kapasitas } \\
\text { koneksi } \\
\text { local } \\
\text { Access ke } \\
\text { IIX atau } \\
\text { koneksi ke } \\
\text { Internasio } \\
\text { nal Link. }\end{array}$ \\
\hline
\end{tabular}

\section{Rekomendasi Perencanaan Peningkatan TIK}

\section{Peningkatan Infrastruktur Jaringan dan Data}

Direkomendasikan untuk menggunakan arsitektur Partial Mesh di jaringan kampus POLTEKBA dengan pertimbangan berikut ini:

1. Beban traffic yang semula diestimasikan dapat dikelola dengan topologi star, saat ini sudah tidak memadai digunakan karena kemampuan dalam mengirim paket berdasarkan IP Address harus dilakukan secara efisien, tepat dan dinamis.

2. Karena kebutuhan peningkatan pelayanan terkait sistem informasi berbasis web, jaringan dan data semakin meningkat maka membutuhkan keberadaan jaringan yang dapat mengintegrasikan seluruh layanan ke pusat layanan data center yang dikelola oleh UPTSI. 


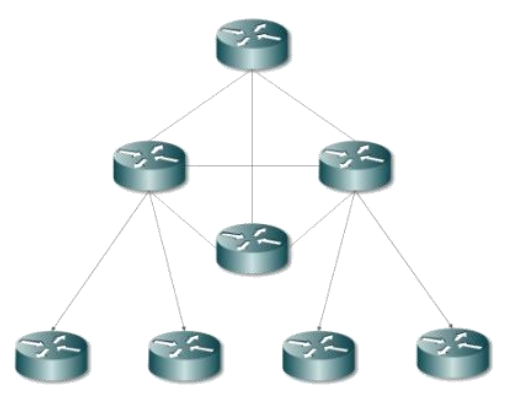

Gambar 1. Topologi Jaringan yang Direkomendasikan

\begin{tabular}{|l|}
\hline \multicolumn{1}{|c|}{ Partial Mesh } \\
\hline Medium cost for WAN link \\
\hline Partial redundancy (back-up) for selected sites \\
\hline Medium bandwidth on selected sites \\
\hline $\begin{array}{l}\text { Connection = number of branch sites + } \\
\text { redundant links }\end{array}$ \\
\hline $\begin{array}{l}\text { Dynamic routing (medium - high complexity) } \\
\frac{n(n-1)}{2}\end{array}$ \\
\hline
\end{tabular}

Direkomendasikan untuk Poltekba, beban jaringan kampus semakin meningkat maka dibutuhkan pusat jaringan atau server yang dapat menyebarluaskan jaringan keseluruh kampus. Media yang digunakan adalah menggunakan kabel fiber optic dan network distribution yang akan disebarkan secara merata diseluruh gedung kampus. Untuk menjaga konsistensi kecepatan internet maka akan dipasang switch access point disetiap lantai gedung kampus.

Arsitektur pusat data yang direncanakan akan memiliki sebuah datawarehouse yang dapat digunakan untuk mengintegrasikan data seluruh unit yang ada di Poltekba, sehingga nantinya informasi yang berasal dari kumpulan beberapa data lewat DBMS dapat digunakan oleh top manajemen dalam mengambil sebuah keputusan. Dengan memperhatikan aspek kompleksitas dan beban data, maka arsitektur Semi Distributed menjadi pilihan di Poltekba.

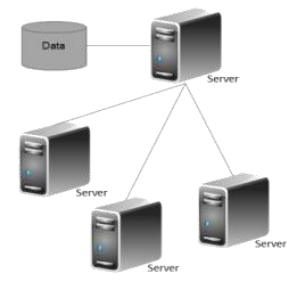

Gambar 2. Arsitektur Pusat Data yang Direkomendasikan

\begin{tabular}{|cl|}
\hline \multicolumn{1}{|c|}{ Fully Centralised } \\
\hline 1. & More secure \\
2. & Easy to access application \\
3. & No Data duplication \\
4. & Easy to perform scheduled backup \\
5. & Easier Database Management and Maintenance \\
\hline 1. & Database Locking \\
2. & Highly depend on central network connection \\
3. & Heavy Database workload \\
4. & High Volume Database \\
\hline
\end{tabular}

2. Perencanaan Sistem Keamanan dan Keselamatan TI

Tindak keamanan sistem informasi diprioritaskan terhadap perlindungan aset infrastruktur TIK yang ada di seluruh gedung kampus Poltekba. Untuk mengantisipasi kejadian yang disebabkan oleh tindakan yang tidak disengaja, seperti : (i) kecerobohan manusia, (ii) kegagalan untuk mengikuti prosedur yang telah dibangun, (iii) personil yang kurang terlatih atau diawasi dan (iv) kehilangan, kerusakan dan data salah tempat maka UPTSI sebagai pengelola SI / TI di Poltekba membutuhkan dukungan peralatan yang bersifat (a) mengawasi, mengamankan dan (c) mencegah kerusakan yang disebabkan oleh : (1) bencana alam, (2) kerusakan peralatan, (3) tindakan yang tidak disengaja dan (4) tindakan disengaja. Berikut ini beberapa kebutuhan peralatan teknologi yang dapat memenuhi beberapa unsur keamanan seperti yang telah disebutkan, diantaranya adalah : 


\begin{tabular}{|c|c|c|}
\hline No & $\begin{array}{l}\text { Tantangan } \\
\text { Terhadap Sistem }\end{array}$ & $\begin{array}{l}\text { Bentuk Pencegahan } \\
\text { Sistem }\end{array}$ \\
\hline 1 & $\begin{array}{ll}- & \begin{array}{l}\text { Bencana Alam } \\
\text { dan Politik }\end{array} \\
- & \text { Tindakan yang } \\
& \text { Disengaja }\end{array}$ & $\begin{array}{lr}\text { Sistem } & \text { CCTV yang } \\
\text { dapat } & \text { memantau } \\
\text { seluruh } & \text { kemanan } \\
\text { gedung } & \text { kampus } \\
\text { Poltekba beserta aset } \\
\text { - aset berharga milik } \\
\text { Negara (seperti : Lab, } \\
\text { peralatan teknologi, } \\
\text { ruang server, dll.) }\end{array}$ \\
\hline 2 & $\begin{array}{ll}- & \text { Tindakan yang } \\
& \text { Tidak Disengaja } \\
- & \text { Tindakan yang } \\
& \text { Disengaja }\end{array}$ & $\begin{array}{l}\text { Akses terbatas } \\
\text { terhadap manusia } \\
\text { yang tidak memiliki } \\
\text { hak untuk masuk ke } \\
\text { ruangan tertentu yang } \\
\text { dianggap vital }\end{array}$ \\
\hline 3 & $\begin{array}{l}\text { Kerusakan Peralatan } \\
\text { dan Software }\end{array}$ & $\begin{array}{l}\text { Alat pemantau dan } \\
\text { pendeteksi kejadian } \\
\text { yang disebabkan oleh } \\
\text { kebakaran dan } \\
\text { kelistrikan di ruang } \\
\text { server dan pusat data }\end{array}$ \\
\hline 4 & $\begin{array}{l}\text { Bencana Alam dan } \\
\text { Politik }\end{array}$ & $\begin{array}{lr}\text { Alarm pemberitahuan } \\
\text { keseluruh } & \text { gedung } \\
\text { kampus } & \text { Poltekba } \\
\text { ketika } & \text { terjadi } \\
\text { kebakaran } & \text { atau } \\
\text { kejadian } & \text { berbahaya } \\
\text { lainnya } & \end{array}$ \\
\hline
\end{tabular}

Tabel 1. Tantangan Keamanan Sistem

UPTSI membutuhkan sebuah sistem yang dapat menjamin ketersediaan seluruh sumber daya TI yang dimilikinya termasuk keselamatan manusia dari berbagai ancaman dan resiko kerja. Peralatan yang tidak aman dapat menyebabkan kecelakaan yang disebabkan oleh listrik, beberapa contoh diantaranya adalah : (a) koneksi longgar, (b) kerusakan instalasi, (c) kesalahan penempatan peralatan dan (d) terdapat bagian yang rusak. Menurut banyak hukum mengenai keselamatan dan kesehatan, organisasi harus menyediakan tempat kerja dimana pekerja tidak akan terkena bahaya bila terjadi kesalahan / kecelakaan [7], pekerja harus menerima pelatihan, instruksi, ,pengawasan dan informasi sehingga mereka terhindar dari bahaya. Saat ini hampir seluruh kegiatan bisnis yang ada di Poltekba didukung berbagai peralatan teknologi yang mungkin bisa saja menimbulkan ancaman bagi manusia disekitarnya akibat kecelakaan listrik. Oleh karena itu UPTSI membutuhkan dukungan peralatan keselamatan yang dapat menjamin sumber daya manusia yang merupakan salah satu komponen penting dalam tata kelola TI. Berikut ini model strategi sistem keselamatan yang direncanakan untuk diimplementasikan guna tindak pencegahan kecelakaan dan pengendalian cidera akibat kecelakaan pada manusia.

\begin{tabular}{|c|c|c|}
\hline No & $\begin{array}{l}\text { Peralatan Sistem } \\
\text { Keselamatan } \\
\text { Manusia }\end{array}$ & Tujuan \\
\hline 1 & $\begin{array}{ll}\text { a. } & \text { Emergency } \\
& \text { Panic Button } \\
\text { b. Silent Panic } \\
\text { Button }\end{array}$ & 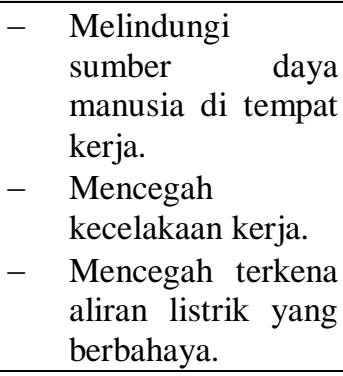 \\
\hline 2 & $\begin{array}{ll}\text { a. } & \text { Smoke Detector } \\
\text { b. } & \text { Sounder and } \\
& \text { Strobe } \\
\text { c. } & \text { Dual Tech } \\
& \text { Motion Sensor } \\
\text { d. Strobe Light } \\
\text { e. Panel Intrusion } \\
& \text { Alarm berbasis } \\
\text { jaringan } \\
\text { f. Speaker } \\
\text { g. Temperature } \\
\text { Sensor }\end{array}$ & 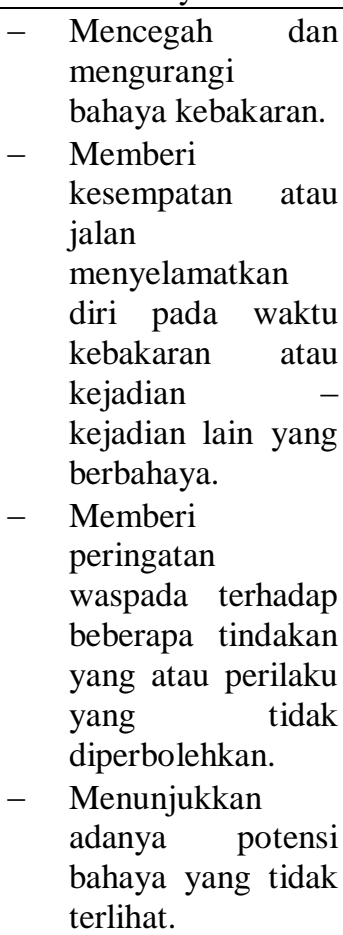 \\
\hline
\end{tabular}

Tabel 2. Sistem Keselamatan Manusia TI

\section{Strategi untuk mencegah kegagalan}

Dari hasil analisa yang dilakukan peneliti terdahulu ada beberapa faktor penentu yang dapat digunakan oleh manajemen TI di Poltekba dalam melakukan peningkatan infrastuktur TIK supaya terhindar dari resiko kegagalan, diantaranya adalah [8] :

1. Identifikasi faktor kontigensi. 
2. Blueprint perancangan tata kelola TI.

3. Penggunaan standar IT Governance (Cobit, ITIL,Coso,dll).

4. Akuntabilitas partisipasi CIO \& CEO dalam menciptakan sebuah strategi yang mudah dimengerti.

5. efektifitas komunikasi dan peran antar stakeholder.

6. Efektifitas kebijakan TI.

7. Dukungan finansial dan sumberdaya manusia

8. Orientasi bisnis dan TI

Dari kedelapan factor tersebut apabila manajemen TI memiliki komitmen untuk menjalankan dengan baik maka akan memperkecil resiko kegagalan dalam melakukan peningkatan infrastruktur TIK di Politeknik Negeri Balikpapan

\section{Kesimpulan}

Kemampuan TIK dalam mendukung keberlanjutan organisasi telah disadari dengan sungguh oleh Poltekba, hal ini terlihat dari komitmen manajemen dalam melakukan peningkatan infrastruktur TIK. Dari tahap perencanaan yang dilakukan maka penelitian ini merekomendasikan kepada manajemen TI untuk menganalisa factor resiko yang dapat menyebabkan kegagalan implementasi TIK diantaranya adalah dengan melakukan perencanaan yang baik. Dari kedelapan factor penentu keberhasilan yaitu dukungan CEO dan CIO serta finansial yang kuat turut menjadi factor penentu dalam keberhasilan peningkatan TIK di Poltekba nantinya. Sedangkan rekomendasi untuk peningkatan infrastruktur jaringan yang direkomendasikan di Poltekba adalah menggunakan topologi jaringan partial mesh sedangkan pusat data menggunakan fully centralized. Hal ini sesuai dengan hasil analisa kebutuhan pengguna di lingkungan kampus serta memperhitungkan kebutuhan TIK dimasa depan. Manajemen TI juga perlu membuat sebuah system keamanan yang dapat menjamin keselamatan pengguna TIK dan sekaligus keamanan peralatan TIK yang diadakan, karena investasi yang akan dikeluarkan oleh manajemen untuk peralatan TIK cukup tinggi dari sisi keuangan.

\section{Daftar Pustaka}

1. [1] M. Iskandar, N. Akma, and M. Salleh, "IT Governance in Airline Industry : A Multiple Case Study," vol. 1, no. 4, pp. 308-313, 2010.

2. [2] P. J. Steinbart, "Accounting Information System 9th Edition Auditing of Computer-Based Information System Chapter 10," Account. Inf. Syst. Account., pp. 1-67, 2003.

3. [3] J. O'Brien, Pengantar Sistem Informasi: Perspektif Bisnis dan Manajerial. Jakarta: Salemba Empat, 2005.

4. [4] W. Setyowati and Winarno, "Analisis Penerimaan Teknologi Sistem Ujian OnlineNasional Teknologi Informasi dan Multimedia, 2015, pp. 1.2-95.

5. [5] J. R. V. Alves and P. Castro, "Information Technology Governance - A Case Study of the Applicability of ITIL and COBIT in a Portuguese Private School," 2009.

6. [6] E. "Analisis Pelaksanaan Tata Kelola Teknologi Informasi di Politeknik Negeri Balikpapan Menggunakan Framework Cobit 4.1," Universitas Gadjah Mada, 2015. 